\title{
Establishment of Harrop, High-Temperature Viscometer
}

by

R. F. Schumacher

Westinghouse Savannah River Company

Savannah River Site

Aiken, South Carolina 29808

D. K. Peeler

This paper was prepared in connection with work done under the above contract number with the U. S. Department of Energy. By acceptance of this paper, the publisher and/or recipient acknowledges the U.S. Government's right to retain a nonexclusive, royalty-free license in and to any copyright covering this paper, along with the right to reproduce and to authorize others to reproduce all or part of the copyrighted paper. 


\section{DISCLAIMER}

This report was prepared as an account of work sponsored by an agency of the United States Government. Neither the United States Government nor any agency thereof, nor any of their employees, makes any warranty, express or implied, or assumes any legal liability or responsibility for the accuracy, completeness, or usefulness of any information, apparatus, product, or process disclosed, or represents that its use would not infringe privately owned rights. Reference herein to any specific commercial product, process, or service by trade name, trademark, manufacturer, or otherwise does not necessarily constitute or imply its endorsement, recommendation, or favoring by the United States Government or any agency thereof. The views and opinions of authors expressed herein do not necessarily state or reflect those of the United States Government or any agency thereof.

This report has been reproduced directly from the best available copy.

Available to DOE and DOE contractors from the Office of Scientific and Technical Information, P.O. Box 62, Oak Ridge, TN 37831; prices available from (615) 576-8401.

Available to the public from the National Technical Information Service, U.S. Department of Commerce; 5285 Port Royal Road, Springfield, VA 22161. 


\section{DISCLAIMER}

Portions of this document may be illegible in electronic image products. Images are produced from the best available original document. 
Westinghouse Savannah River Co.

Savannah River Technology Center

Key Words: glass, viscosity, measurement, calibration

Date: $\quad$ September 30, 1998

\section{Establishment of Harrop, High-Temperature Viscometer - (U) \\ by}

Q75 R.F. Schumacher \& D.K. Peeler

\section{Summary}

This report explains how the Harrop, High-Temperature Viscometer was installed, calibrated, and operated. The report includes assembly and alignment of the furnace, viscometer, and spindle, and explains the operation of the Brookfield Viscometer, the Harrop furnace, and the UDC furnace controller. Calibration data and the development of the spindle constant from NIST standard reference glasses is presented. A simple operational procedure is included.

\section{Introduction}

Viscosity is a liquid defining property which has great importance for the manufacture and control of glass materials. The viscosity is related to the force required to move one layer of a fluid past another, or to cause one solid surface to move past another when there is a layer of fluid between the two surfaces. The application of a shearing force causes the atoms or molecular groups in the liquid to undergo displacement with respect to each other that continues with time so long as the application of force.continues. [1] The time rate of deformation or shear rate is linearly related to the shearing stress on the liquid through Newton's law of viscosity:

$$
\mathrm{F} / \mathrm{A}=\mu \mathrm{dv} / \mathrm{L}
$$

Where $\mathrm{F}$ is the force, $\mathrm{A}$ the area of the plates, $\mathrm{dv}$ the velocity difference between the plates, and $L$ the separation between the plates. The symbol $\mu$ is the physical constant for a given material and conditions and is called viscosity. A simple schematic follows as Figure 1.

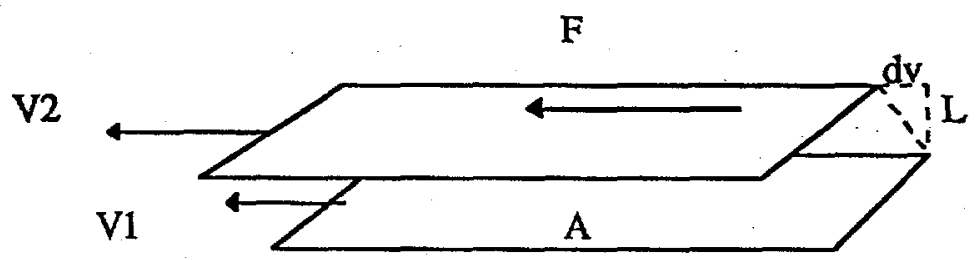

Figure 1. Schematic Representation of Newton's Law.

Using this simple representation, viscosity may also be defined by Equation 2 .

$$
\text { Viscosity }=\mu=\text { Shear Stress } / \text { Shear Rate }
$$

Eq. 2 
The fluidity of a liquid is defined as the reciprocal of the viscosity. A Newtonian fluid is independent of the rate of shear e.g., twice the force would move the liquid twice as fast. Fortunately, glass is considered to be a Newtonian liquid except perhaps at extreme shear rates, such as those found in high speed forming operations.

Viscosity is measured in Pa.s (pascal second), the accepted SI unit, although the older unit Poise is still more commonly used in discussions of glass. For conversion, 1 Pa.s is equal to 10 Poise. The term centipoise or $\mathrm{cP}$ is $1 / 100$ th of a Poise. This report will continue discussions with the use of Poise. Additional conversion units are listed below:

$\begin{array}{llll} & \text { SI units } & & \text { cgs units } \\ \text { Viscosity } & 1 \mathrm{mPa} . s & = & 1 \mathrm{cP} \\ \text { Shear Stress } & 1 \mathrm{Newton} / \mathrm{m} 2 & = & 10 \text { dyne } / \mathrm{cm} 2 \\ \text { Torque } & 1 \text { Newton-m } & = & 107 \text { dyne-cm. }\end{array}$

Glass viscosity curves are often described mathematically by the Fulcher-FogelTammann equation or more simply the Fulcher equation: [2]

$$
\log (\mu)=-A+B \times 1000 /(T-T o)
$$

where $A, B$, and To are empirical constants. The temperature $(T)$ is the measured in degrees Celsius. This equation permits reasonable extrapolation of measurements to specific temperatures or viscosities. The determination of the three constants by manual methods is difficult, however, advanced software packages such as JMP®, Deltagraph $\circledast$, etc. can solve the three constants through curve fitting. The constants tend to vary within the following limits:

$$
\begin{array}{lll} 
& \text { A } & 2 \text { to } 5 \\
\text { and } & \text { To } & 5 \text { to } 8 \\
& \text { To } & 400 \text { to } 0 .
\end{array}
$$

Viscosity is one of the key physical property determinations for development of the vitrification process for nuclear or hazardous wastes. The viscosity - temperature relationship is a key parameter in the rate at which the glass melt homogenizes and refines. The glass viscosity establishes the melting temperature range and controls the rate of pouring through a given opening. In the glass industry, the viscosity also controls the ability to form the glass into the desired shape or form. The viscosity of glasses are often measured between 50 Poise to levels as high as 10 to the 14 th power. Certain glass viscosity-temperature points have been commonly defined as shown in Table 1 . The typical methods for the viscosity determinations are also noted.

Table 1. Viscosity Ranges and Methods of Determination

\begin{tabular}{lll}
\hline Log Viscosity & Common & Method of \\
(Poise) & Glass Term & Determination \\
\hline
\end{tabular}

2.0

4.0

7.65

13.0

14.5 $\begin{array}{ll}\text { Melting Point } \mid & \text {...... Rotating Cylinder or } \\ \text { Working Point } & \text { Bubble Rise }\end{array}$

Softening Point 1 Penetration

Annealing Point I.... Fiber Elongation

Strain Point $\mid$ Beam Bending

Page 2 of 23 
The rotating type viscometer, the most common determination method, was first introduced by Margules [3] and further adapted by successive investigators [4-10]. Two types of rotating viscometers have generally been employed to measure the high temperature viscosity of glass. In one case the crucible is rotated and the spindle deflection is measured. In the other case, the spindle is rotated and the viscosity determined from the percent torque and the rate of rotation[11]. This report will consider only the latter case.

\title{
Experimental
}

Set up and Alignment

The Harrop SP-4A High Temperature Glass Viscometer consists of the equipment listed in Table 2. A simple electrical schematic of the lay out is shown as Figure 2 and a detail of the equipment arrangement is presented in Figure 3.

Table 2. Harrop High Temperature Glass Viscometer

\author{
Harrop platinum wound, water cooled, tube furnace $\left(1600^{\circ} \mathrm{C}\right)$, \\ Motorized Furnace Lift, \\ Honeywell Universal Digital Controller (UDC3000), \\ Brookfield DV-II+ Programable Viscometer, \\ Viscometer Base and Stand, \\ Platinum Crucible and Spindle \\ Brookfield Oils and NIST Glass Standards.
}

This equipment was designed jointly by Harrop Industries Inc. and the Brookfield Engineering Laboratories Inc. [11]. The Clemson University, Environmental Technologies Laboratory initially established the equipment settings [12]. The furnace was designed to use a limited amount of radioactive glass and measure the viscosity over a fairly wide range. of viscosity and temperature.

The UDC controller requires the attachment of three lines from the viscometer base to the UDC controller. The heavy black power cable provides power to the furnace and the two smaller leads provide the thermocouple inputs to the controller [13]. All connections should be clearly labeled as shown in Figure 2. The UDC is supplied with 110 volt power from a common outlet as shown. The viscometer base has a plug to a wall outlet which provides power to the motorized furnace lift. The Brookfield Viscometer must be attached to the Viscometer Base and also requires 110 volt power. The Brookfield viscometer has a hand adjustment to raise and lower the instrument. The Harrop furnace has a motor driven lift and cooling water must be supplied to the furnace to prevent overheating of the outer surface.

Alignment of the viscometer base, the crucible holder/platinum crucible and the Brookfield viscometer is critical to this measurement. A level bubble is attached to the base and to the Brookfield to assist alignment [14]. An independent leveling devices such as a carpenters level is recommended. The crucible holder is an alumina tube which can be adjusted by loosening a bolt on the bottom of the viscometer base. The viscometer, hang down wire, and spindle should be centered in the alumina tube and then the platinum crucible. The spindle should be true. Note that the hook which attaches to the Brookfield has a left hand thread. Some of the Brookfield shafts do not appear to turn true and cause oscillation at high speeds. This could be confirmed by evaluating other Brookfield viscometers. 
Initially during the set up, the platinum spindle should just touch the bottom of the platinum crucible. Locate the Brookfield viscometer travel stop at this position on the support bar. Mark the alumina tube, crucible holder at the base and then another mark at 0.200 inches or $0.50 \mathrm{~cm}$ above the first mark. Loosen the alumina tube with the set screw and lower the sample holder to the new mark. This will insure that the spindle is off the bottom of the crucible by $0.200 \mathrm{inch}$. When the furnace is at high temperature $\left(1500^{\circ} \mathrm{C}\right)$ the spindle and crucible will increase in length due to thermal expansion by about 0.120 inch. This allows 0.080 inch between the spindle and the bottom of the crucible for clearance. The dimensions of the crucible and spindle are presented in Figure 4. The spindle has a maximum diameter of 0.344 inch and the crucible well has an inside diameter of 0.500 inch. The difference is only 0.156 inch or roughly about $1 / 16$ th of an inch on either side of the spindle.

The furnace position has been marked on the right side of the stand and should be operated at the upper stop position "0" to perform the viscosity determination. See Figure 5 for the approximate furnace dimensions and the furnace positions. A check of the furnace gradient was made and is shown as Figure 6 . This data shows that the flat portion of the gradient is in or near the raised stop position (0 position).

If alignments are not correct and the spindle shaft is not straight there will be poor operation of the system, particularly at high rotational speeds ( $>60 \mathrm{rpm})$. The HADV-II Brookfield viscomter has some axial play and creates a portion of the allignment problem. This may require correction at a later date. The Brookfield also has some side to side play on the Brookfield stand.

\section{Set Up of Brookfield Programmable Viscometer}

Turn on the power to the Brookfield Viscometer with the power switch on the back left hand side of the unit. Allow it to warm for about ten minutes. Per the directions from the viscometer, remove the hangdown wire and spindle and allow the instrument to autozero. A schematic of the Brookfield face is reproduced as Figure 7. Press the up arrow and the speed setting should appear while the motor is off (OFFRPM). The speed of the HADVI+ can be adjusted over two independent scales:

$$
\begin{aligned}
& 0,0.5,1,2,2.5,4,5,10,20,50, \text { and } 100 \mathrm{RPM} \text { or } \\
& 0,0.3,0.6,1.5,3.0,6,12,30 \text {, and } 60 \mathrm{RPM} \text {. }
\end{aligned}
$$

At speeds above 60 RPM there may be excessive oscillation of the spindle. Use the arrows to scroll through the speeds, use SET SPEED to select the speed, and use the MOTOR ON/OFF to turn on the motor. The SELECT SPINDLE and ENTER/AUTO RANGE are not used at this time. The \% Torque will be used in these measurements. Some caution is required to insure the starting of the motor at a low speed so that the torque is not too high. The speed can be adjusted upward during measurement. This unit has additional capabilities which are presently unnecessary for this viscosity determination.

\section{Set Up of Honeywell UDC Controller}

Turn on the power to the UDC by pushing on the "Power On" switch on the face of the controller. See Figure 8. The "Stand By" switch, white light, should be pushed so that power is available to the instrumentation but the furnace relay contact is open. The "Power On" switch cannot operate unless it is in the "Stand By" mode. The Honeywell controller can now be adjusted. 
To check the tuning of this controller press the "Setup" button to see SETUP TUNING. Next press the "function' button to see 10.0 PROP BD. Keep pressing the "function" button to check tuning parameters. See Attachment 1 for the record of the original settings for all functions.

To establish the heating schedule press the "Setup" button twice to see SP RAMP. Prepare a heating program as shown in Figure 9. This will reduce mistakes in the heating program. Press the function button to see ENABLE - SP PROGRAM. Press function button again to start the programming segment with START SEG -1 . Continue pressing function button and follow directions on Figure 9 to establish a heating program. The heating program can contain up to 12 segments. The up and down arrows are used to adjust ramp rates, soak set points, and soak times. The start up of the furnace will be covered under the Procedures section.

\section{Calibration Standards}

\section{Silicone Fluids}

Before viscosity can be determined with the non-standard platinum spindle and crucible it is necessary to calibrate the unit with standard materials. There are standard Brookfield fluids and NIST glass standards available for this purpose. Both were used in this set up and the results will be reported here [15]. The use of these standard materials permits the calculation of a constant which can later be used to convert the Brookfield \% Torque data to viscosity. The constant may be calculated from the following formula:

$$
\mathrm{K}=[(\text { (Standard viscosity) } \times \mathrm{RPM}] / \% \text { Torque } \quad \mathrm{Eq} .4
$$

The Brookfield fluids are easy to use but the calibration does not include the effects of high temperature. These fluids are recommended for initial set-up but the NIST glasses are recommended for actual calibration of the viscometer. The Brookfield fluids are identified and characterized in Table 3. There are two types of general purpose fluid. One is standardized at $25^{\circ} \mathrm{C}$ and the other, thermal fluid, which can be used over the temperature range of 25.0 to $149^{\circ} \mathrm{C}$. In this calibration the high temperature HT 30000 was employed and $K$ was found to be between 240 and 247 . These fluids are recommended for initial set $\mathrm{u}$, but the NIST glass calibration is required for the high temperature calibration.

\begin{tabular}{|c|c|c|c|}
\hline $\begin{array}{l}\text { Brook } \\
\text { Part \# }\end{array}$ & $\begin{array}{l}\text { Nominal } \\
\text { Viscosity-cP }\end{array}$ & $\begin{array}{l}\text { Specific } \\
\text { Gravity }\end{array}$ & $\begin{array}{l}\text { Temp } \\
{ }^{\circ} \mathrm{C}\end{array}$ \\
\hline \multicolumn{4}{|c|}{ General Purpose Fluids } \\
\hline $5 \mathrm{cps}$ & 5 & 0.92 & 25.0 \\
\hline $10 \mathrm{cps}$ & 10 & 0.94 & \\
\hline $50 \mathrm{cps}$ & 50 & 0.96 & “ \\
\hline $100 \mathrm{cps}$ & 100 & 0.96 & « \\
\hline $500 \mathrm{cps}$ & 500 & 0.97 & " \\
\hline $1000 \mathrm{cps}$ & 1,000 & 0.97 & " \\
\hline $5000 \mathrm{cps}$ & 5,000 & 0.97 & “6 \\
\hline $12500 \mathrm{cps}$ & 12,500 & " & “ \\
\hline $30000 \mathrm{cps}$ & 30,000 & « & “ \\
\hline $60000 \mathrm{cps}$ & 60,000 & « & “ \\
\hline $100000 \mathrm{cps}$ & 100,000 & “ & “ \\
\hline
\end{tabular}


Table 3. Continued

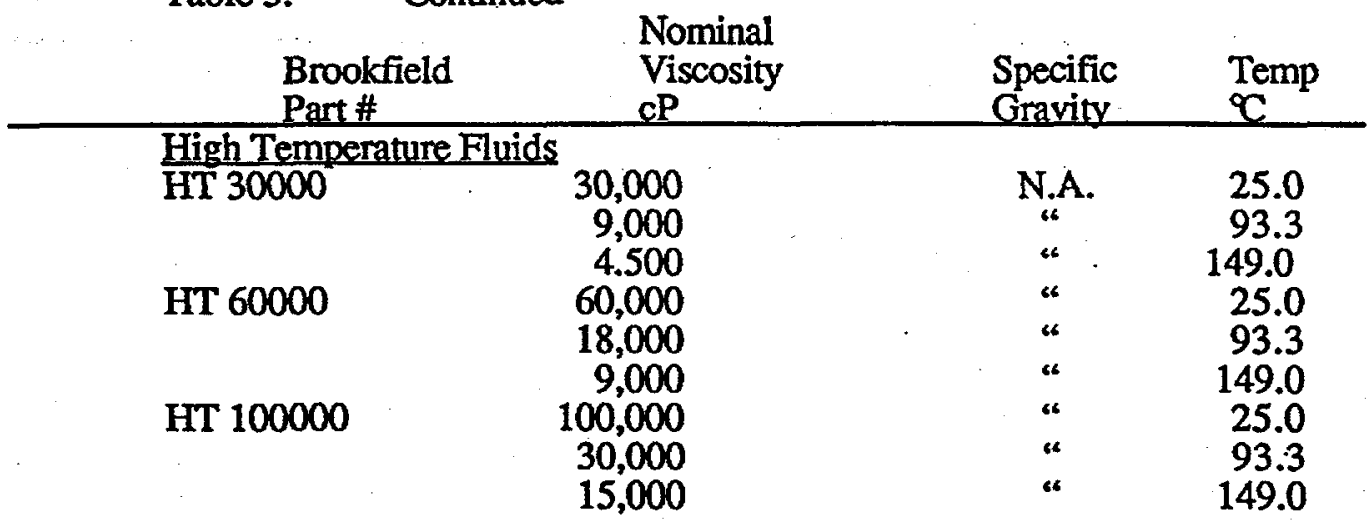

\section{NIST Standard Glasses}

Standard glasses for viscosity may be obtained from the National Institute of Standards and Technology, Gaithersburg, MD. Two glasses were obtained for this purpose: a borosilicate No. 717a and a soda-lime glass No. 710a. The viscositytemperature relationships and densities are presented in Tables 4 and 5 . The use of these glasses is recommended to develop the viscosity spindle constant. This method should replace the need for separate thermocouple or viscometer calibration as the data should be traceable to NIST as long as the viscometer set up, thermocouple, or furnace conditions are not changed.

Table 4. Standard Reference Material 717a - Borosilicate Glass

\begin{tabular}{lllll}
\hline $\begin{array}{llll}\text { Glass No. } \\
\text { NIST }\end{array}$ & $\begin{array}{l}\text { Temp } \\
\text { PC }\end{array}$ & $\begin{array}{l}\text { Visc. } \\
\text { Poise }\end{array}$ & Log Visc. & $\begin{array}{l}\text { Est. Density } \\
\text { (gm/cc) }\end{array}$ \\
\hline Borosilicate & & 100 & 2.00 & $2.29 @ 25^{\circ} \mathrm{C}$ \\
$717 \mathrm{a}$ & 1555 & 178 & 2.25 & \\
& 1466 & 316 & 2.50 & \\
& 1388 & 562 & 2.75 & \\
& 1318 & 1,000 & 3.00 & \\
& 1256 & 1,778 & 3.25 & \\
& 1201 & 3,162 & 3.50 & \\
& 1151 & 5,623 & 3.75 & \\
& 1106 & 10,000 & 4.00 & \\
& 1065 & 17,782 & 4.25 & \\
& 1028 & 31622 & 4.50 & \\
& 993 & 56,234 & 4.75 & \\
& 961 & 100,000 & 5.00 & \\
& 932 & 177,828 & 5.25 & \\
& 905 & 316,228 & 5.50 &
\end{tabular}

Fulcher Equation, $\quad$ Log Visc.(Poise $)=-1.5602+4852.2 /\left(T\left({ }^{\circ} \mathrm{C}\right)-192.462\right)$ 
Table 5. Standard Reference Material 710a Soda-Lime-Silica

\begin{tabular}{lllll}
\hline $\begin{array}{l}\text { Glass No. } \\
\text { NIST }\end{array}$ & $\begin{array}{l}\text { Temp. } \\
\text { C C }\end{array}$ & $\begin{array}{l}\text { Viscosity } \\
\text { Poise }\end{array}$ & $\begin{array}{l}\text { Log } 10 \\
\text { Vis. }\end{array}$ & $\begin{array}{l}\text { Density } \\
\text { gram/ce (Est.*) }\end{array}$ \\
\hline Soda Lime Silica & 1464 & 100 & 2.00 & $2.55 @ 25^{\circ} \mathrm{C}$ \\
710 a & 1432 & 126 & 2.10 & \\
& 1387 & 178 & 2.25 & \\
& 1319 & 316 & 2.50 & \\
& 1259 & 562 & 2.75 & \\
& 1205 & 1,000 & 3.00 & \\
& 1157 & 1,778 & 3.25 & \\
& 1113 & 3,162 & 3.50 & \\
& 1037 & 10,000 & 4.00 & \\
& 973 & 31,622 & 4.50 & \\
& 918 & 100,000 & 5.00 &
\end{tabular}

Fulcher Equation, $\log$ Viscosity (Poise) $=-1.729+4560 /\left(\mathrm{T}\left({ }^{\circ} \mathrm{C}\right)-240,8\right)$

* Density of 1826 soda lime NIST standard.

\section{Calibration Results}

The viscometer should be calibrated with one or both of the NIST glass standards as required. The initial calibration of the top cooled Harrop Furnace with the 717a glass is presented as Table 6 . The plotted data is shown as Figure 11. The actual data taken during these runs is presented as Attachments 2 and 3 . The two constant determinations were averaged and the best straight line fit was obtained. The equation for the spindle constant is presented at the bottom of Table 6 .

Table 6 Calibration with NIST 717a Borosilicate Glass

\begin{tabular}{llllc}
\hline $\begin{array}{l}\text { Crucible } \\
\text { Temp. }\end{array}{ }^{\circ} \mathrm{C}$ & $\begin{array}{l}\text { Viscos. } \\
\text { (Poise) }\end{array}$ & $\begin{array}{l}\text { Spindle } \\
\text { RPM }\end{array}$ & $\begin{array}{l}\text { Avg. \% } \\
\text { Torque }\end{array}$ & $\begin{array}{c}\text { Calc. } \\
\text { K Value }\end{array}$ \\
\hline $8 / 19 / 98$ & & & & Glass Wt. 5.988 gr \\
1513 & 130.1 & 30 & 26.88 & 145.2 \\
1406 & 274.3 & 30 & 51.12 & 161.0 \\
1299 & 668.1 & 12 & 48.9 & 163.9 \\
1193 & 1947 & 6 & 69.6 & 167.8 \\
1088 & 7211 & 1.5 & 62.7 & 172.5 \\
$8 / 27 / 98$ & & & & Glass Wt. 5.966 gr \\
1512 & 130.9 & 30 & 21.7 & 181.0 \\
1405 & 276.4 & 30 & 41.8 & 198.4 \\
1298 & 674.2 & 12 & 39.6 & 204.3 \\
1192 & 1969 & 6 & 56.17 & 210.3 \\
1087 & 7312 & 1.5 & 50.4 & 217.6
\end{tabular}

Average Spindle Constant $\mathrm{K}=272.04-0.069137 \times$ Temp $^{\circ} \mathrm{C}$. 


\section{Viscosity Determination Procedures - Glass}

1) The Harrop/Brookfield viscometer should be setup and all units connected per schematics presented in Figures 2 to 4 . See the previous section on the set up and allignment of the unit. The furnace, sample holder, and Brookfield viscometer should be leveled and aligned. The carpenters level should be used to check all surfaces. The hang down wire and spindle should be attached to the viscometer to check the allignment with the center of the ceramic tube and the crucible. The hang down rod and spindle should be straight and true when ratating below $60 \mathrm{rpm}$. When the spindle is lowered into the crucible it should come to rest 0.200 inch from the bottom of the crucible. Raise the Brookfield Viscometer and spindle 2 to 3 inches above the stop.

2) Setup the Brookfield viscometer and become familiar with its operation. See Figure 5 and previous section covering the viscometer. Set the viscometer at a relatively slow speed.

3) Setup the Honeywell UDC controller checking the setup and general configuration. See Figure 6, Attachment 1 and the previous section. Establish the heat up and hold schedule similar to that shown in Figure 7.

4) Determine the density of the sample glass at room temperature.[16] Weigh out 2.6 cc of the glass (Density $\times 2.60=$ grams of glass) and place into the platinum crucible. Place the platinum crucible on the alumina sample holder. Carefully raise the furnace with the lift. Some assistance by hand is required to raise the furnace.

5) Insure that the cooling water is flowing to the furnace. A slight vibration will be felt when the Tygon $\otimes$ tube is compressed between the fingers. On the UDC controller, push the Manual/Auto button to Auto. An " $A$ " should appear at the top of the Honeywell control. Push the Run/Hold button to Run and an " $R$ " should appear on the left side of the Honeywell control. Check the "Lower Display" for the set point. It may be necessary to adjust the Set Point with the Select Set Point switch to ensure the amp loading is not to high on start up (approx. 70 to $80^{\circ} \mathrm{C}$ ). Push the Std By/ Run button to Run - a blue light should appear. Something similar to the following should be seen on the Honeywell screen:

\begin{tabular}{|c|c|c|c|}
\hline & Honeywell Screen & & Digital Read Out \\
\hline & & A & Temperature Indicator \\
\hline (run) $)$ & $\begin{array}{ll}R & 105 \\
\text { SP } & 108\end{array}$ & & 98 (crucible) \\
\hline
\end{tabular}

6) Check ammeter - initially should have a low value ( $<5$ amp). If not adjust Set Point.

7) To Stop program advancement simply push Run/Hold to Hold. To stop heating the furnace push StdBy/Run to Stand By (White Light). To completely reset the program shut controller off and start at Step 3 again.

8) When the furnace reaches the high temperature hold and the glass has melted and homogenized, lower the Brookfield Instrument and spindle to the stop. 
9) The Brookfield should be set for a slow speed and gradually increased to obtain a $\%$ Torque reading of at least $10 \%$ or more. The initial high temperature hold is important to allow bubbles to escape and the glass to equilibrate. A time of at least one half hour to three quarters hour should be allowed before measurements are taken.

10) Three to four measurements should be obtained at five minute intervals while the furnace is holding. The following data should be recorded: Set Point, Furnace Temperature, Sample Temperature, RPM, \% Torque and Time. See Figure 10 for a typical data sheet. Stop the Brookfield instrument until the furnace temperature has reached the next hold.

11) Wait till furnace has decreased in temperature to the next lower hold and has equilibrated for about one quarter hour. Reduce speed on the viscometer with the set speed adjustment prior to inital start up. Obtain three to four measurements at this temperature at about 5 minute intervals. If more time is needed to obtain additional measurements, press the Hold button which stops the program advance.

12) Repeat step 10 and 11 until all measurements are taken. This usually requires 5 to 6 hold periods. It is better to obtain 5 or 6 precise measurements than many measurements which were not given sufficient time to equilabrate.

13) Slowly raise the Brookfield and spindle 1 inch above stop point and allow glass to drain off the spindle. Raise the spindle another 1 inch to clear the crucible. Allow the furnace to cool to room temperature in this position. Turn off the furnace power and when the furnace has cooled down turn off the water cooling.

14) Remove the crucible and place upside down in an alumina crucible and place in a furnace. Heat the crucible to about $1000^{\circ} \mathrm{C}$ and allow it to drain. The crucible will require cleaning in HF for several days to clean. Special training must be obtained for work with $\mathrm{HF}$.

15) The viscosity is calculated with the following formula.

Viscosity (Poise) $=\mathrm{K} \times \%$ Torque/RPM.

16) The calibration of the viscometer using the NIST glass should be carried out after any major distrubance of the viscometer set up or the furnace etc. The unit should be calibrated after every 20 to 30 measurements. 


\section{References}

1. A. K. Varshneya, "Fundamentals of Inorganic Glasses," Chapter 9, p183-210,

Academic Press, San Diego, CA, 1994.

2. G.S. Fulcher, "Analysis of Recent Measurements of the Viscosity of Glasses,"J. Amer. Ceram. Soc., 8: [6] 339-55, (1925)

3. M. Margules, "Uber die Bestimmung des Reibungs und Gleitungs Coefficienten aus ebenen Bewegungen einer Flssigkeit,' Sitzber.Akad.Wiss.Wien, 83, Part II, 588 (1881).

4. S. English, J.Soc. Glass Tech. Trans., 7, 25 (1923) and 8, 205 (September, 1924).

5. E.W. Washburn, G.R. Shelton, and E.E. Libman, Univ. of Illinois Eng. Exp. Station, Bull. 140, 74 (April, 1924).

6. H.R. Lillie, "Viscosity Measurements in Glass," J. Amer. Ceram. Soc., 12 [8] 516-529, (1929).

7. H.A. Robinson \& C.A. Peterson, "Viscosity of Recent Container Glass," J. Amer. Ceram. Soc., 27, [5], 129-138, (1944).

8. R.L. Tiede, "Improved Apparatus for Rapid Measurement of viscosity of Glass at High Temperatures," J.Amer.Ceram.Soc. 42 [11] 537-541, (1959).

9. A. Napolitano \& E.G. Hawkins, "Viscosity of a Standard Soda-Lime-Silica Glass," J Research of NBS, 68A [5], 439-448, (1961)

10. ASTM C 965-81, "Measuring Viscosity of Glass Above the Softening Point," 1010-1016, Part 17, Annual book of ASTM Standards.

11. A. Blum, "Instruction Manual for Harrop Model SP-4A, High Temperature Viscometer," Serial No. 10137, May 1997, Harrop Industries, Inc.

12. T. Pruett, "Final Report on Shakedown of Glass Viscometer to Support the Pu Program at SRTC," Task Order 228, SCUREF, Clemson Environmental Technologies Laboratory, Clemson, SC, April 15, 1998.

13. "UDC 3000, Universal Digital Controller Product Manual," No. 51-52-25-07E, October, 1995, Fort Washington, PA.

14. "Brookfield DV-II+ Programable Viscometer Operating Instructions," Manual No. M/97-164, Brookfield Engineering Laboratory, Inc. Stoughton, MA.

15. Notebook No. WSRC-NB-89-30, (E-57157) 74-89, R.F. Schumcher

16. GTOP 3-038 "Density of Glass by Buoyancy," 5/31/96. 
Page 11 of 23

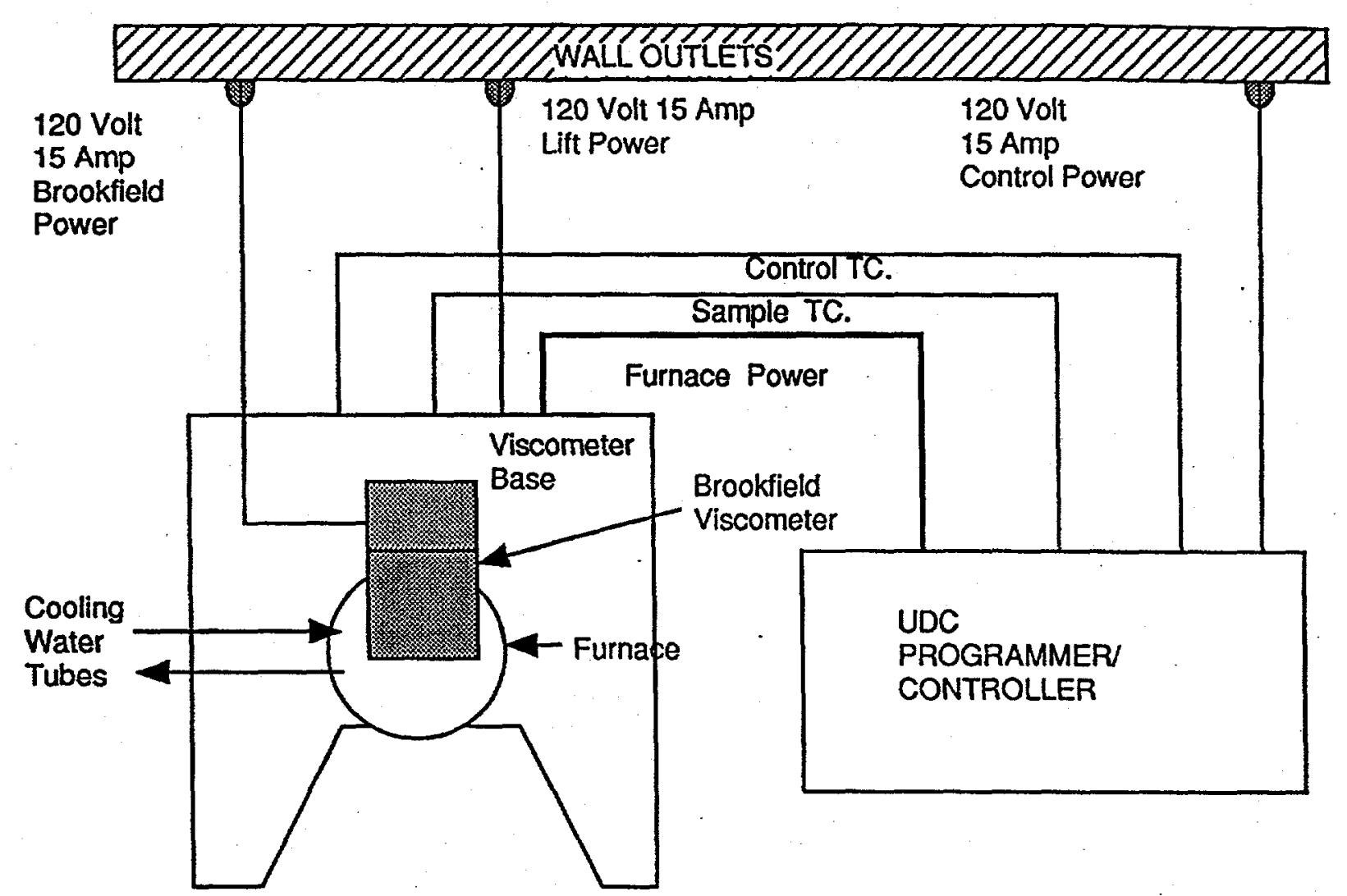

SP4A VISCOMETER

Figure 2. Simple Schematic Harrop Viscometer 
Page 12 of 23

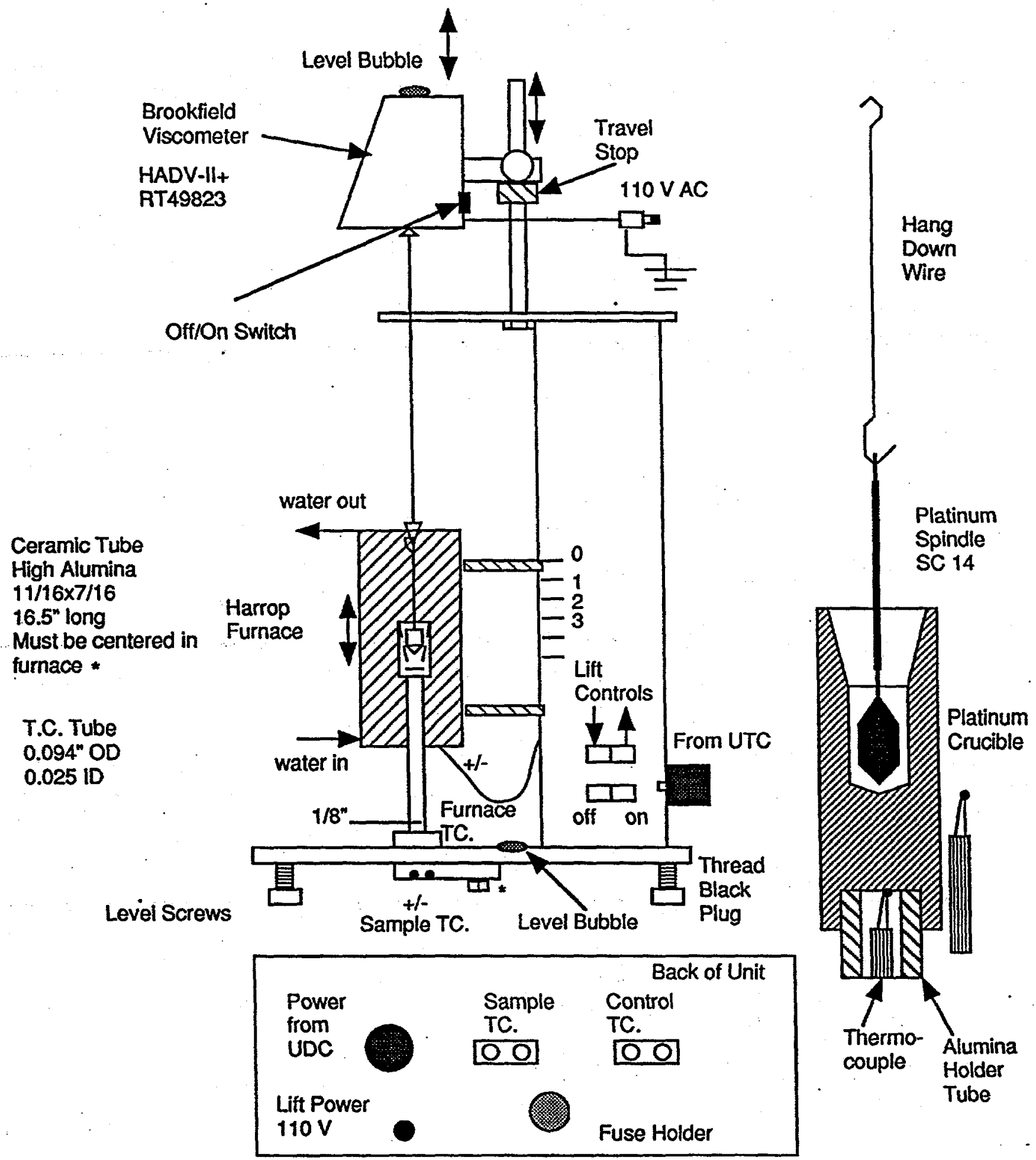

Figure 3. Harrop High Temperature Viscometer 


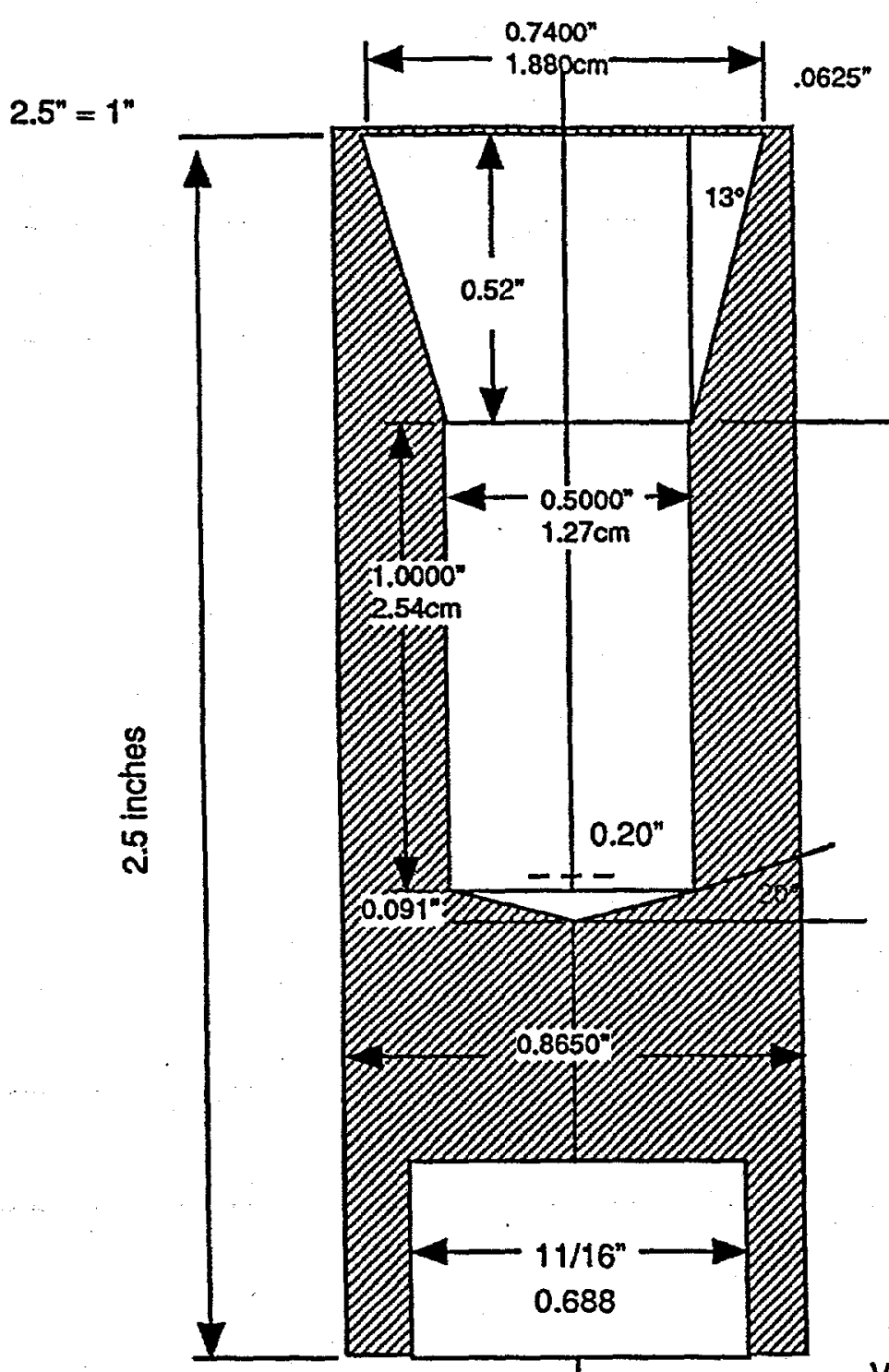

Vol. Cone $=1 / 3 \Pi r 2 h$ $\tan \varnothing=h / r \quad h=r \tan \varnothing$ Vol Cone $=1 / 3 \Pi r 3 \tan \varnothing$

Vol Cone $=1 / 3 \Pi(.25) 3 \tan 20^{\circ}$

Vol. Cone $=0.006$ in $3=0.098 \mathrm{~cm} 3$

Vol. Cylinder $=\Pi \mathrm{r} 2 \mathrm{~h}$

Vol. Cylinder $=\Pi 1.0 / 16$

Vol Cylinder $=0.196 \mathrm{in} 3=3.218 \mathrm{~cm} 3$

Vol. Cup $=0.098+3.218=3.316 \mathrm{~cm} 3$

Vol Upper Cone Section

$=1 / 3 \Pi h\left(r 2+r^{\prime} 2+r r^{\prime}\right)$

$\mathrm{h}=0.12 / \tan \varnothing=0.520$

$=1 / 3 \Pi 0.520(0.291)$

$=0.158 \mathrm{in} 3=2.596 \mathrm{~cm} 3$

C.L.
Page 13 of 23 C.L.

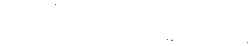

Calc. Glass Lovel

0.125

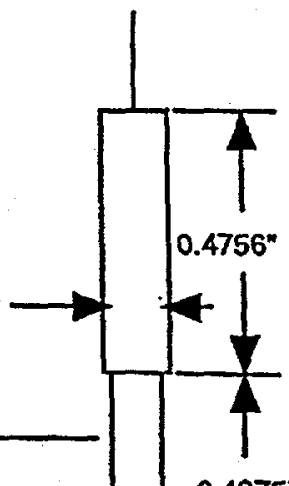

0.332

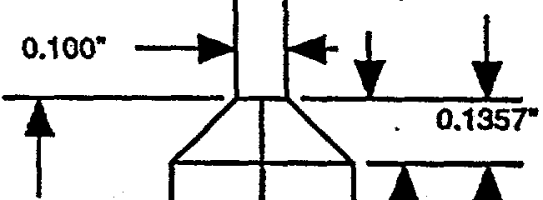

$0.6340^{\prime \prime}$

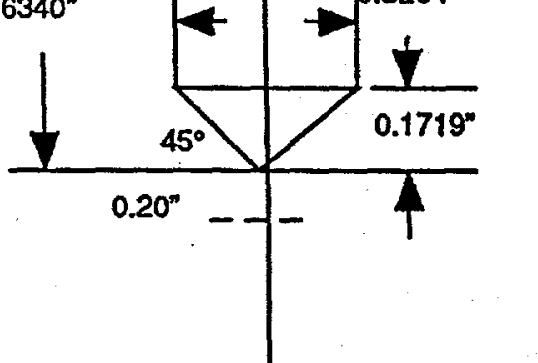

Vol. Cone $=1 / 3 \Pi \mathrm{r} 2 \mathrm{~h}$

$=1 / 3 \Pi(0.1719) 3$

$=0.0053$ in $3=.087 \mathrm{~cm} 3$

Vol. Cylinder $=\Pi \mathrm{r} 2 \mathrm{~h}$

$=\Pi(0.1719) 2 \quad 0.3264$

$=0.030 \mathrm{in} 3=0.496 \mathrm{~cm} 3$

Vol Upper Cone $=1 / 3 \Pi h\left(r^{2}+r^{\prime} 2+r r^{\prime}\right)$

$=1 / 3 \Pi 0.1357(0.0406)$

$=0.0058 \mathrm{in} 3=0.095 \mathrm{~cm} 3$

Vol. Upper Cylinder $=\Pi \mathrm{r} 2 \mathrm{~h}$

$=\Pi .00250 .332$

$=.0026 \mathrm{in} 3=.043 \mathrm{~cm} 3$

Vol Spindle $=0.087+0.496+0.095+0.043$

$=.721 \mathrm{~cm} 3$

Vol Glass $=3.316-.721=2.595 \mathrm{~cm} 3$

Vol. Glass $=2.6 \propto$

Wt Glass $=2.6 \times$ Glass Density

Figure 4. Platinum Crucible and Spindle 
Page 14 of 23

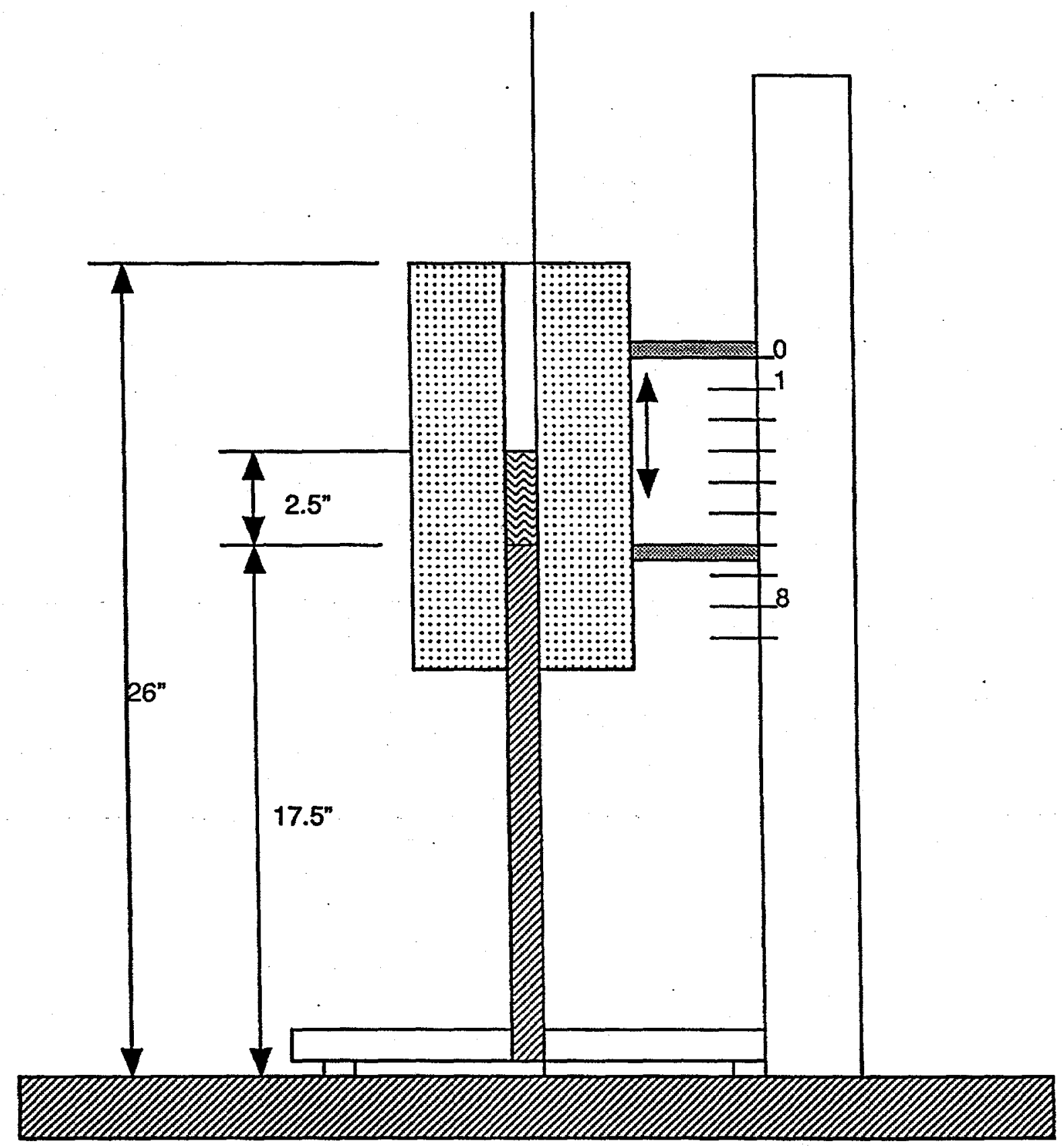

Figure 5. Approximate Dimensions of Viscosity Set Up 
Page 15 of 23

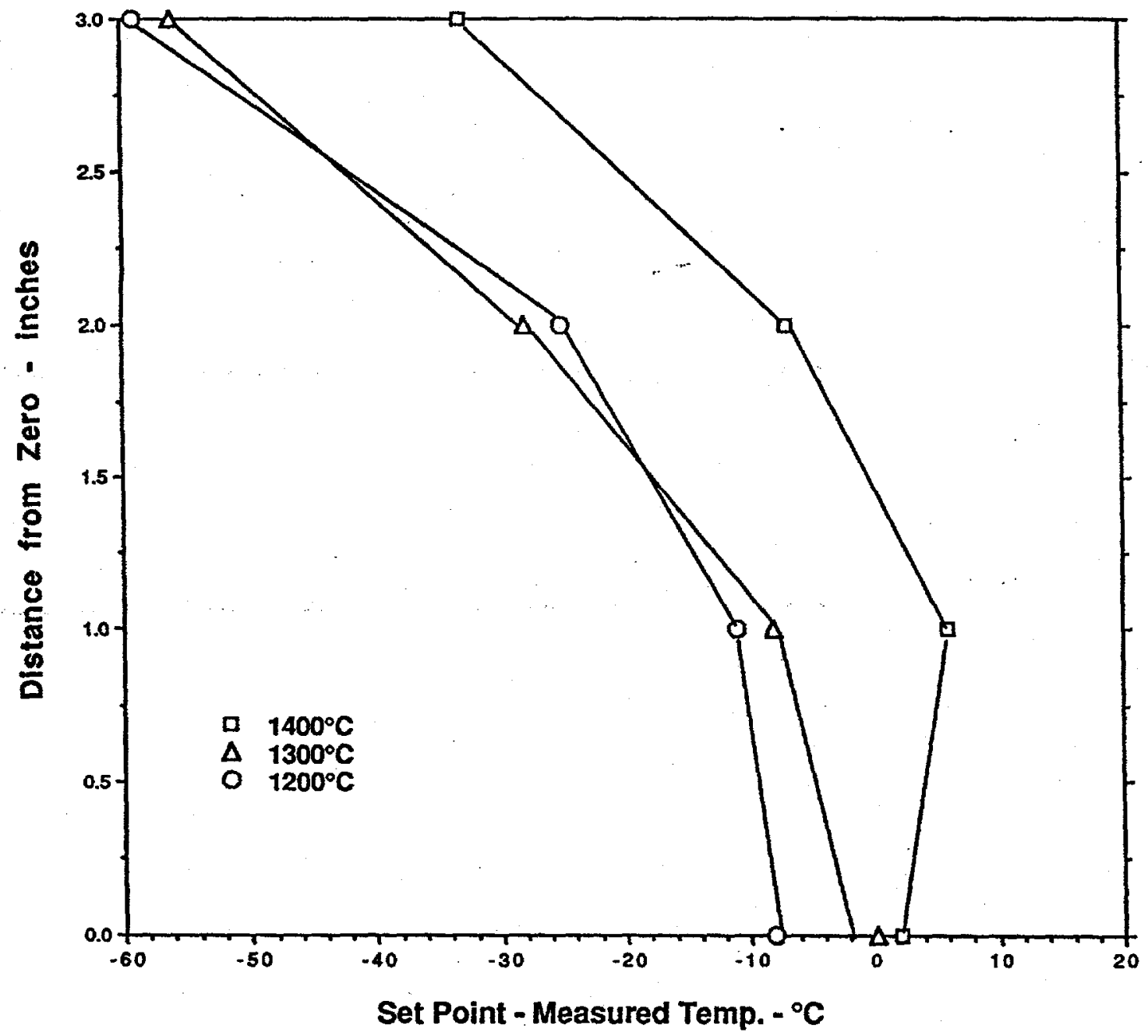

Figure 6. Furnace Gradient Top Cooled Harrop Visc. RFS - 8-14-98 
Page 16 of 23

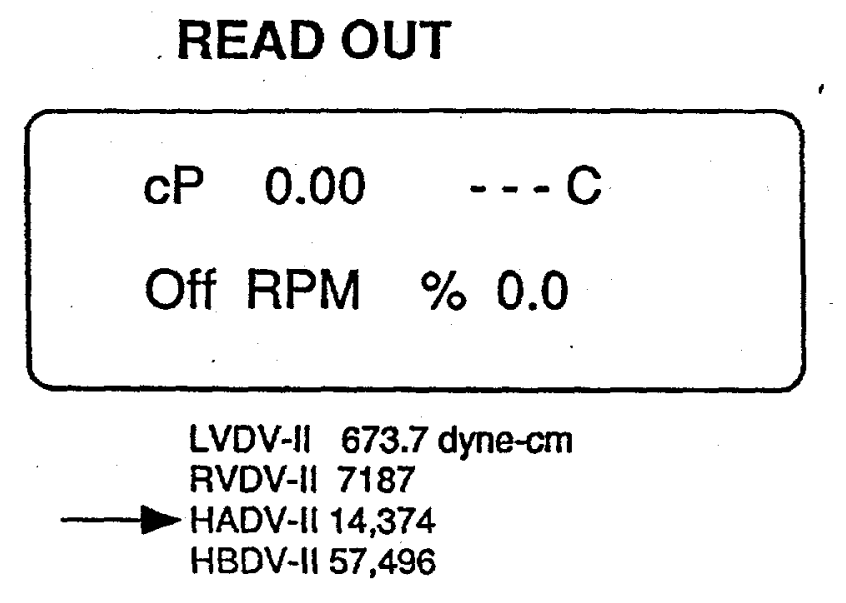

Motor On/Off

Escape exits options

Options Menue

Causes unit to run at selected speed

Motor
on/off Options

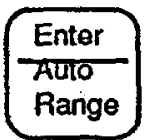

Execute current option

Presents maximum torque
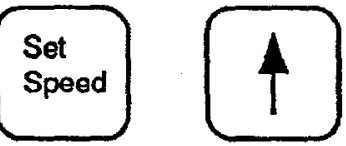

Select Spindle
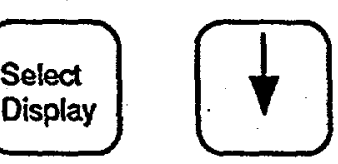

Print

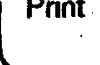

Spindle selection

Selects data/parameter display CP,SS,SR, \%

Torque 
Page 17 of 23
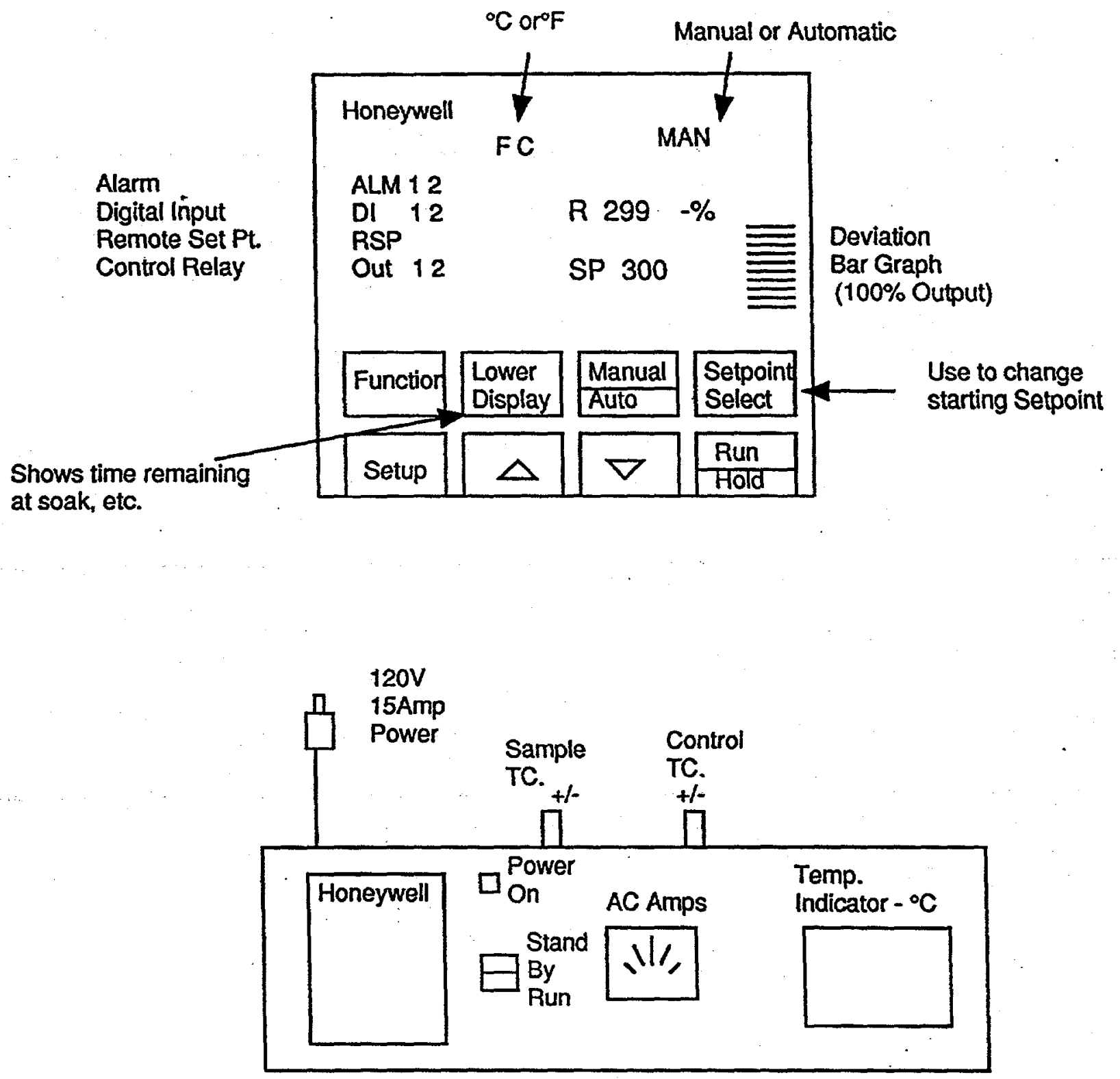

Figure 8. Honeywell UDC Controller 
Page 18 of 23

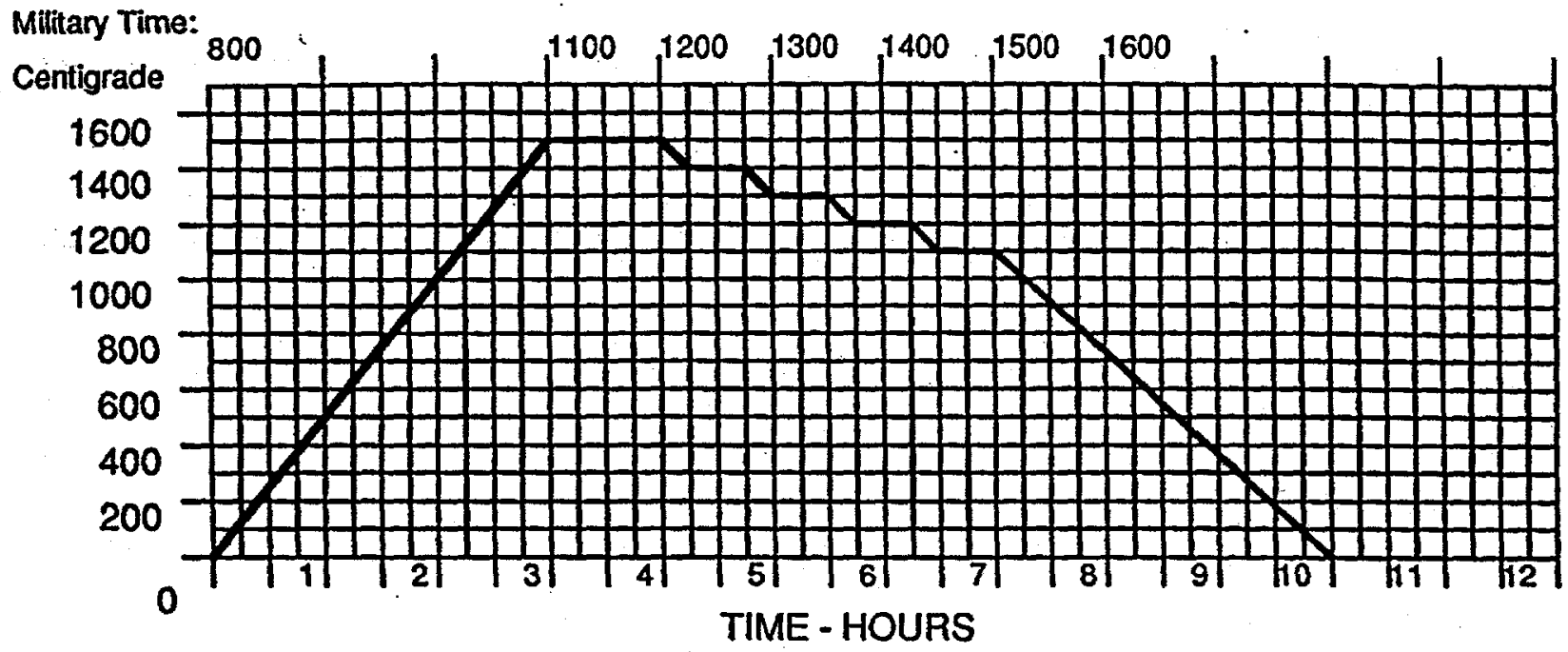

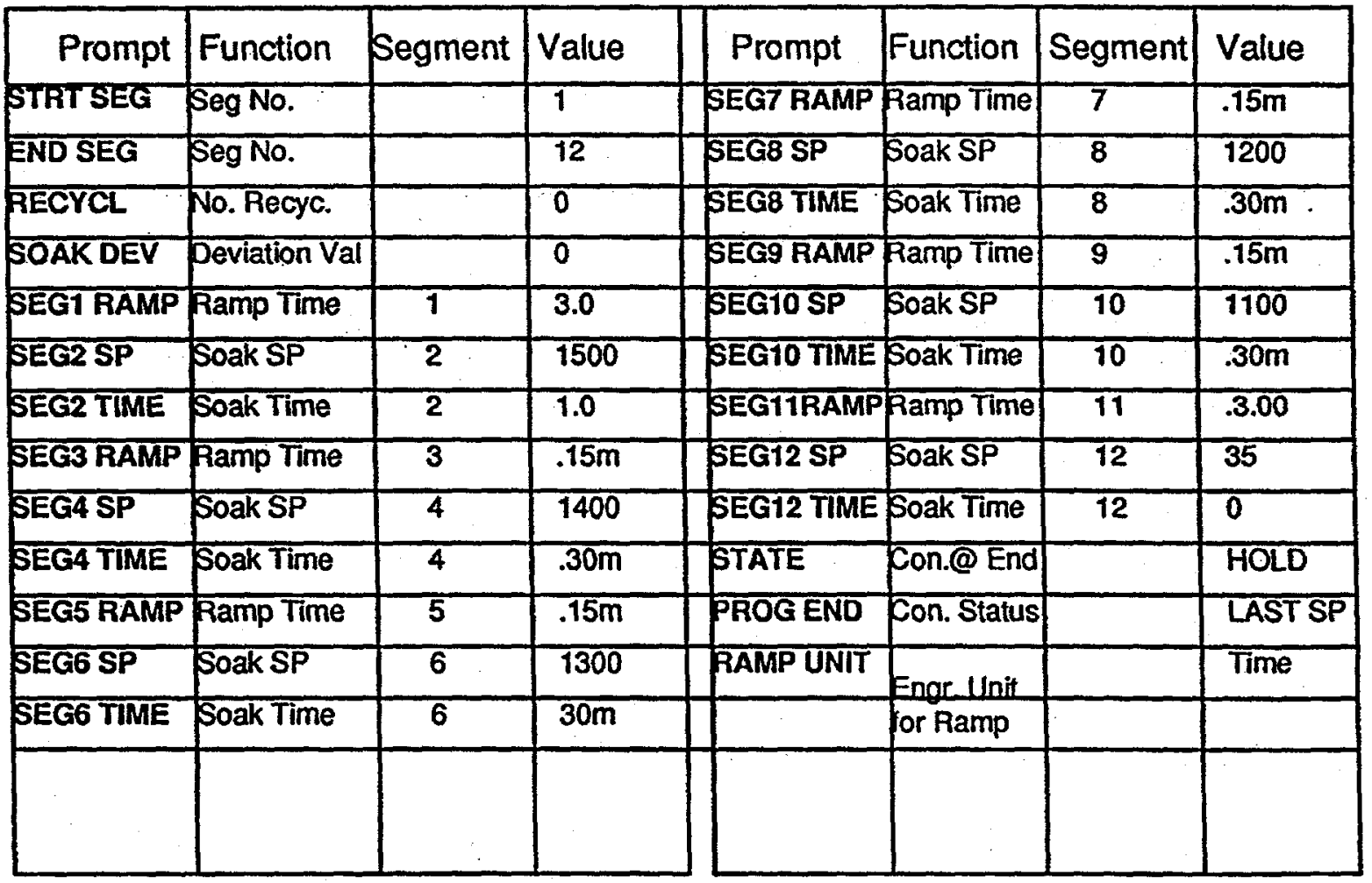

SET UP to SET UP TUNING

FUNCTION to parameters

SET UP to SP RAMP

FUNCTION to SP Prog. Enable

FUNCTION to above....

\section{Figure 9. Ramp/Soak Profile and Input to. Program}


Figure 10. Viscosity Test Report

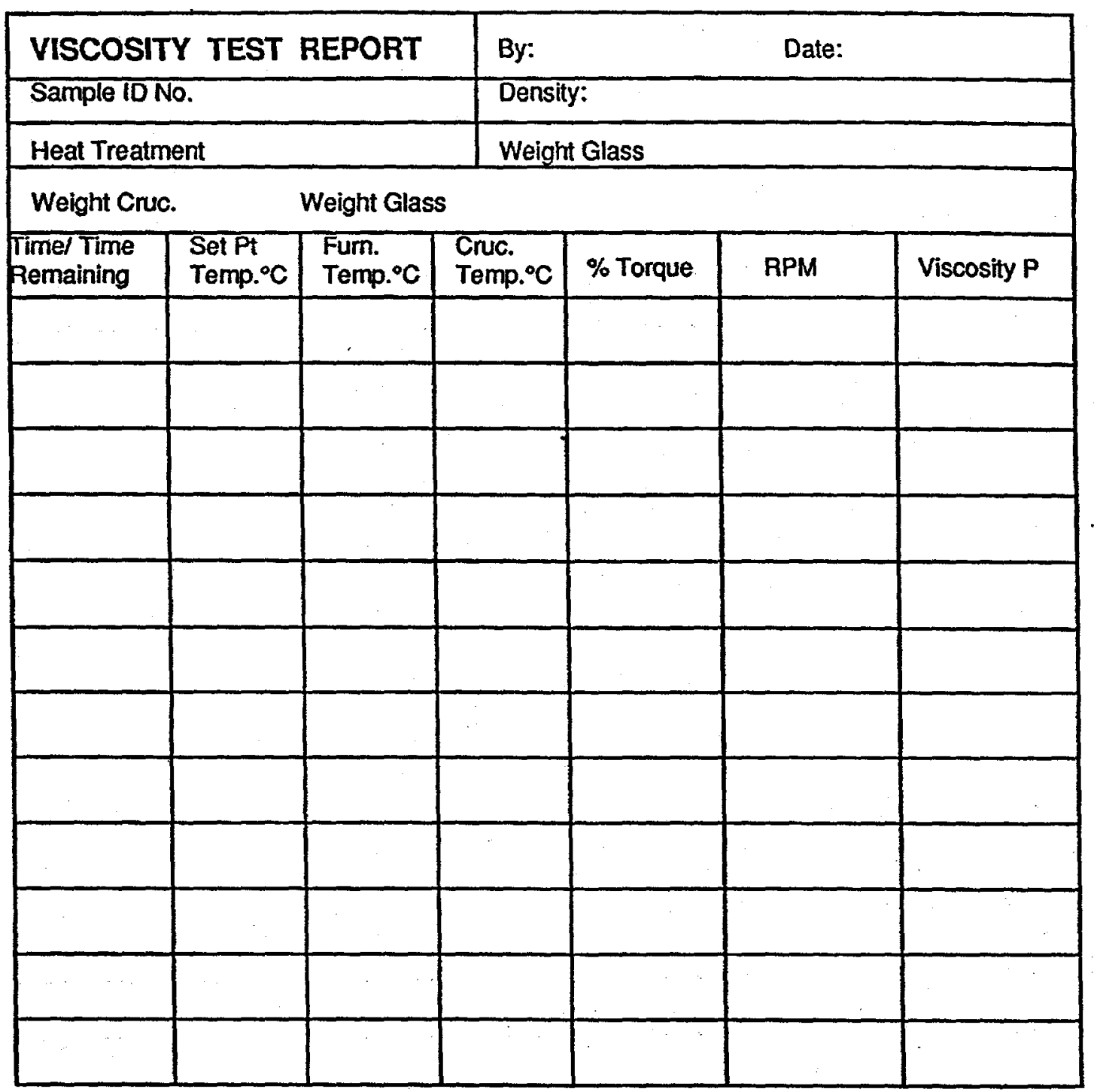

Glass Weight $=2.6 \times$ Glass Density

Spindle Constant, $K=$ (Visc $\times$ RPM) $/ \%$ Torque

Viscosity $=\mathrm{Kx} \%$ Torque / RPM

Comments on Determination

Signed:

Date: 
Page 20 of 23

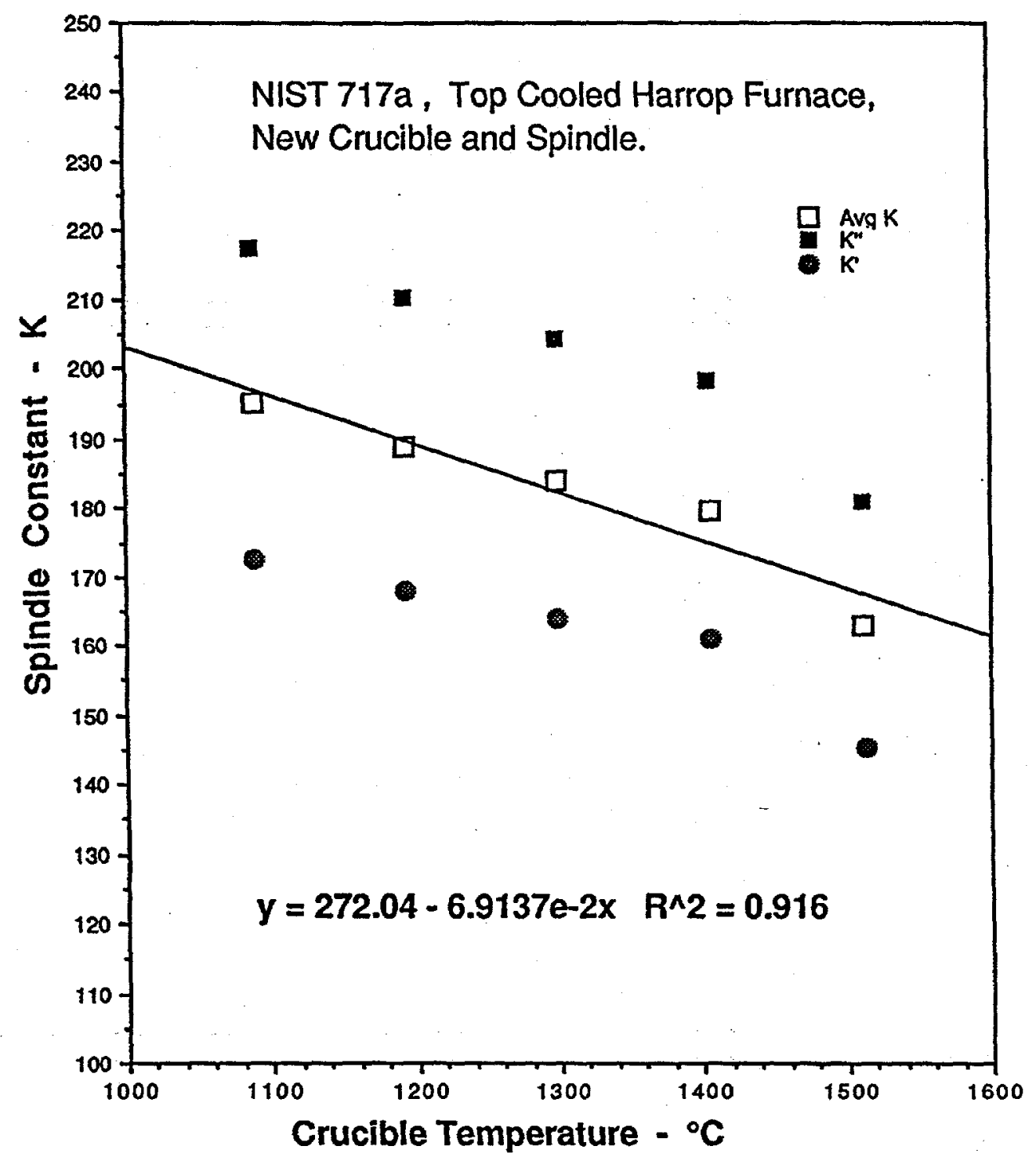

Figure 11. Graph of Measured Spindle Constants at Temperature - ${ }^{\circ} \mathrm{C}$. 


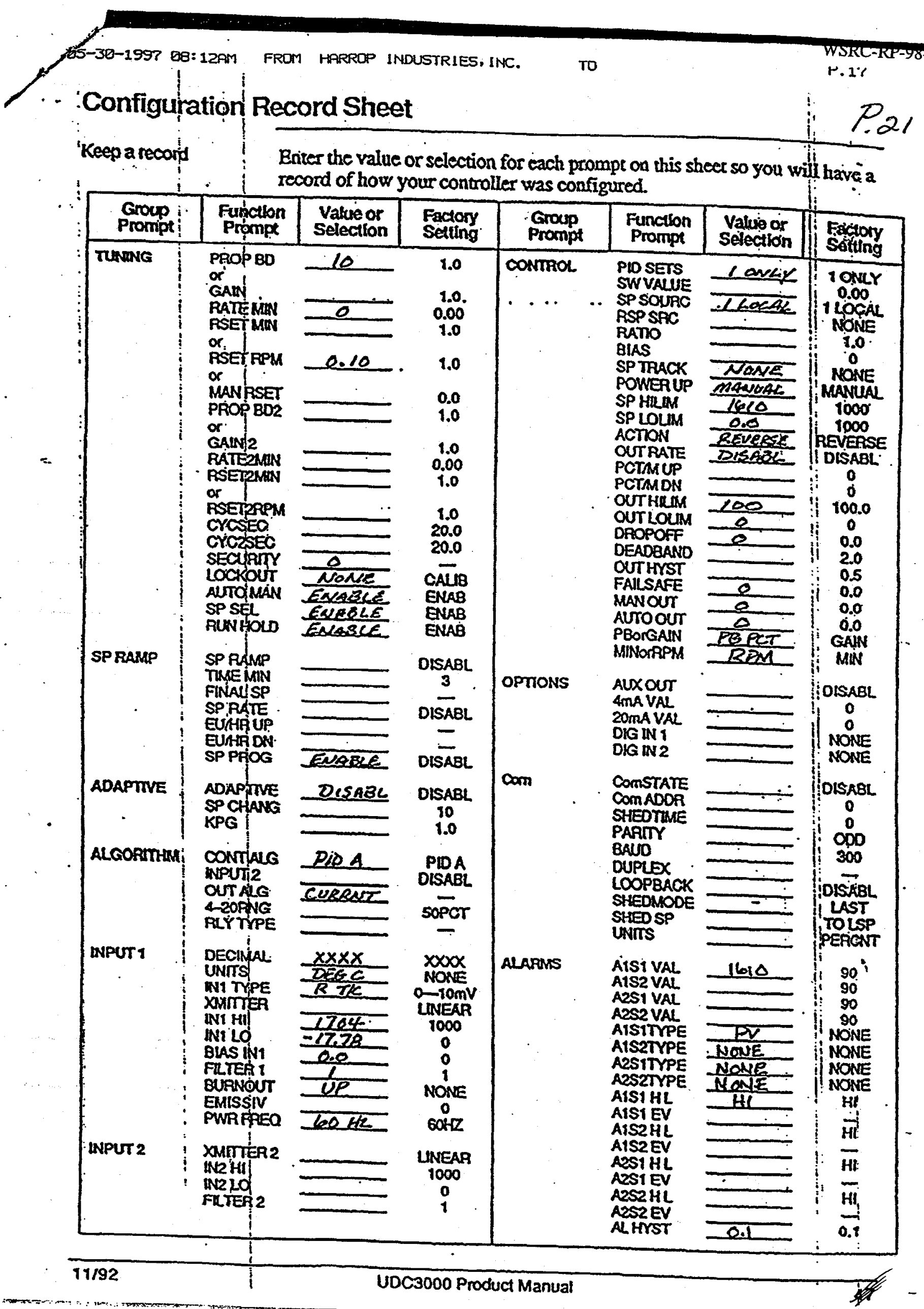




\begin{tabular}{|c|c|c|c|c|c|c|}
\hline \multicolumn{3}{|c|}{ CALIBRATION WITH NIST 717a } & & & \multirow{2}{*}{\begin{tabular}{|r|} 
Attachment 2 \\
Glass Wt: \\
\end{tabular}} & \multirow[b]{2}{*}{$5.988 \mathrm{gr}$} \\
\hline & & & & & & \\
\hline Date: & $8 / 19 / 98$ & FPS & & & & \\
\hline \multirow[t]{2}{*}{ Time } & Minute & Sot Point & Furnace & Sample & $\mathrm{FPM}$ & Torque \\
\hline & Remaining & Temp. $0^{\circ} \mathrm{C}$ & Temp. $-^{\circ} \mathrm{C}$ & Temp. ${ }^{\circ} \mathrm{C}$ & Setting & Reading \\
\hline 1140 & $13 \mathrm{H}$ & 1500 & 1499 & 1511 & 30 & 48.8 \\
\hline 1145 & $13 \mathrm{H}$ & * & 1500 & 1513 & $\cdots$ & 39.0 \\
\hline 1150 & " & 4 & . & - & 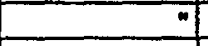 & 42.0 \\
\hline 1155 & 12 & - & 1 & -1 & 1 & 28.4 \\
\hline 1200 & $11 H$ & 7 & 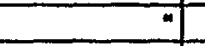 & 7 & 60 & 王 \\
\hline 1205 & $11 \mathrm{H}$ & -1 & it & 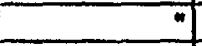 & 30 & 30.8 \\
\hline 1210 & 11H & 1 & -1 & 7 & " & 27.0 \\
\hline 1215 & 7 & 1 & 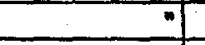 & - & -1 & 27.0 \\
\hline 1220 & $5 \mathrm{H}$ & ") & $"$ & -1 & 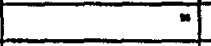 & 26.6 \\
\hline \multirow[t]{2}{*}{1225} & 1H & 1 & $\pi$ & 7 & 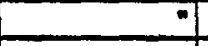 & 26.6 \\
\hline & & & & & Average & 26.88 \\
\hline 1300 & 16 & 1400 & 1399 & 1406 & 30 & 51.2 \\
\hline 1305 & 10 & - & 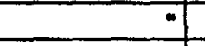 & 1 & . & 51.1 \\
\hline 1310 & 5 & 7 & n & 4 & 1 & 51.1 \\
\hline \multirow[t]{2}{*}{1315} & 2 & 1 & 1400 & 4 & I & 51.1 \\
\hline & & & & & Average & 51.12 \\
\hline 1340 & 20 & 1300 & 1296 & 1297 & 12 & 50.0 \\
\hline 1345 & 15 & " & 1298 & 1299 & 1 & 49.2 \\
\hline 1350 & 10 & -1 & 1299 & 1300 & 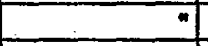 & 48.9 \\
\hline 1355 & 5 & 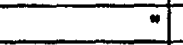 & . & " & . & 48.8 \\
\hline \multirow[t]{2}{*}{1400} & 2 & "1 & 1 & 7 & ( & 48.8 \\
\hline & & & & & Average & 48.92 \\
\hline 1430 & 15 & 1200 & 1198 & 1192 & 6 & 70.3 \\
\hline 1435 & 10 & 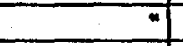 & 1199 & 1193 & 4 & 69.8 \\
\hline 1440 & 5 & -1 & $\cdots$ & $=$ & 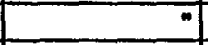 & 69.6 \\
\hline 1445 & $5 \mathrm{H}$ & $\because$ & -1 & 7 & 7 & 69.6 \\
\hline \multirow{2}{*}{1450} & 0 & $"$ & - & 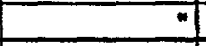 & " & 69.4 \\
\hline & & & & & Average & 69.60 \\
\hline 1515 & 20 & 1100 & 1096 & 1085 & 1.5 & 64.8 \\
\hline 1520 & 15 & 1 & 1098 & 1087 & 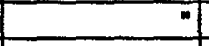 & 63.4 \\
\hline 1525 & 10 & 1 & 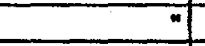 & 1088 & 7 & 62.4 \\
\hline \multirow[t]{6}{*}{1530} & 5 & -1 & 1099 & 1088 & n & 62.3 \\
\hline & & & & & Average & 62.70. \\
\hline & & & & & & \\
\hline & \multicolumn{3}{|c|}{ SPINDLE CONSTANT CALCULATION } & & & \\
\hline & Log Viscosity & & & & & \\
\hline & Fulcher Eq. & Reading & Avg.Reading & Spindle Const. & & \\
\hline Temp- ${ }^{\circ} \mathrm{C}$ & Poise & $\mathrm{FPM}$ & $\%$ Torque & $\mathrm{K}$ & & \\
\hline 1513 & 130.08 & 30 & 26.88 & 145.2 & & \\
\hline 1406 & 274.3 & 30 & 51.12 & 161.0 & & \\
\hline 1299 & 668.1 & 12 & 48.92 & 163.9 & & \\
\hline 1193 & 1947 & 6 & 69.6 & 167.8 & & \\
\hline \multirow[t]{6}{*}{1088} & 7211 & 1.5 & 62.7 & 172.5 & & \\
\hline & & & & & & \\
\hline & & \multicolumn{3}{|c|}{$K=1 \mathrm{~V} i s c(\mathrm{P}) \times$ RPMV $\%$ Torque } & & \\
\hline & & & & & & \\
\hline & & & & & & \\
\hline & & & Page 22 of 23 & & & \\
\hline
\end{tabular}




\begin{tabular}{|c|c|c|c|c|c|c|}
\hline \multicolumn{3}{|c|}{ CALIBRATION WITH NIST 717a } & & & \multirow{2}{*}{\begin{tabular}{|r|} 
Attachment 3 \\
Glass Wt:
\end{tabular}} & \multirow[b]{2}{*}{$5.966 \mathrm{gr}$} \\
\hline & & & & & & \\
\hline Date: & $8 / 27 / 98$ & PPS & & & & \\
\hline Timo & Minute & Set Point & Furnace & Sample & PPM & Torque \\
\hline & Remaining & Temp. $=0 \mathrm{C}$ & Temp. ${ }^{\circ} \mathrm{C}$ & Temp. ${ }^{-0} \mathrm{C}$ & Setting & Reading \\
\hline 1050 & 31 & 1500 & 1501 & 1512 & & \\
\hline 1055 & 27 & " & 1500 & 1511 & 30 & 38.3 \\
\hline 1100 & 23 & II & 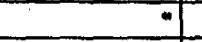 & 1512 & " & 25.8 \\
\hline 1105 & $18 \mathrm{H}$ & a &. & - & . & 22.2 \\
\hline 1110 & . & 7 & - & 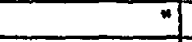 & ") & 21.7 \\
\hline 1115 & -1 & .1 & $\pi$ & 1 & "I & 21.9 \\
\hline 1120 & 13 & "I & .) & .) & -7 & 21.7 \\
\hline 1125 & 8 & II 1 &. &. & 7t & 21.6 \\
\hline \multirow[t]{2}{*}{1130} & 2 & I & -1 & .1 & 7 & 21.6 \\
\hline & & & & & Average & 21.70 \\
\hline 1150 & 24 & 1400 & 1395 & 1400 & 30 & 43.3 \\
\hline 1155 & 20 & 4 & 1397 & 1402 & 7 & 42.4 \\
\hline 1200 & 16 & " & 1398 & 1405 & 7 & 42.0 \\
\hline 1205 & 12 & 7 & 1399 & -1 & "I & 41.7 \\
\hline 1210 & 7 & 4 & 4 & 4 & - & 41.8 \\
\hline \multirow[t]{2}{*}{1215} & 3 & 4 & -1 & 1406 & 7 & 41.7 \\
\hline & & & & & Average & 41.80 \\
\hline 1240 & 23 & 1300 & 1295 & 1293 & $\begin{array}{r}12 \\
\end{array}$ & 41.8 \\
\hline 1245 & 18 & -1 & 1298 & 1297 & 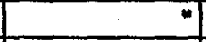 & 40.2 \\
\hline 1250 & 13 & .1 & 1298 & 4 & . & 39.8 \\
\hline 1255 & 9 & $\because$ & 1299 & II & ") & 39.6 \\
\hline 1300 & 5 & 4 & -1 & 4 & 4 & 39.5 \\
\hline \multirow[t]{2}{*}{1304} & 1 & .1 & & 7 & -7 & 39.5 \\
\hline & & & & & Average & 39.60 \\
\hline 1325 & 23 & 1200 & 1195 & 1186 & 6 & 60.2 \\
\hline 1330 & 18 & 4 & 1197 & 1190 & -1 & 57.5 \\
\hline 1335 & 13 & -1 & 1198 & 1191 &. & 56.5 \\
\hline 1340 & 8 & 7 & 1199 & 1192 & .1 & 56.1 \\
\hline \multirow[t]{2}{*}{1.345} & 3 & . & & &. & 55.9 \\
\hline & & & & & Average & 56.17 \\
\hline 1410 & 21 & 1100 & 1095 & 1081 & $\begin{array}{r}1.5 \\
\end{array}$ & 53.9 \\
\hline 1415 & 18 & & 1097 & 1085 & -1 & 52.2 \\
\hline 1420 & 13 & 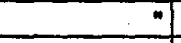 & 1098 & 1086 & .1 & 50.8 \\
\hline 1425 & 8 & 7 & 1099 & 1087 & 7 & 50.4 \\
\hline \multirow[t]{5}{*}{1430} & 3 & 1 & 4 & 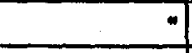 & 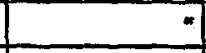 & 50.0 \\
\hline & & & & & Average & 50.40 \\
\hline & SPINDLE CO & NSTANT CA & LCULATION & & & \\
\hline & Log Viscosity & & & & & \\
\hline & Fulcher Eq. & Reading & Avg.Reading & Spindie Const. & & \\
\hline Temp-० & Poise & $P P M$ & $\%$ Torque & $\mathrm{K}$ & & \\
\hline 1512 & 130.9 & 30 & 21.7 & 181.0 & & \\
\hline 1405 & 276.4 & 30 & 41.8 & 198.4 & & \\
\hline 1298 & 674.2 & 12 & 39.6 & 204.3 & & \\
\hline 1192 & 1969 & 6 & 56.17 & 210.3 & & \\
\hline \multirow[t]{4}{*}{1087} & 7312 & 1.5 & 50.4 & 217.6 & & \\
\hline & & & $=\operatorname{Visc}(\mathrm{P}) \times \mathrm{RP}$ & PMY \% Torque & & \\
\hline & & & & & & \\
\hline & & & Page 23 of 23 & & & \\
\hline
\end{tabular}


Westinghouse Savannah River Co. Savannah River Technology Center

Distribution:

E.W. Holtzscheiter, 773-A

C.R. Goetzman, 773-A

N.E. Bibler, 773-A

L.F. Landon, 704-1T

C.T. Randall, 704-T

D.A. Crowley, 773-43A

J.R. Harbour, 773-43A

D.F. Bickford, 773-43A

C.M. Jantzen, 773-A

D.K.Peeler,773-43A

A.D. Cozzi, 773-43A

T.L. Fellinger, 773-A

I.A. Reamer, 773-A

J.M. Pareizs, 773-A

R.J. Workman, 773-A

STI, 703-43A, (4)
WSRC-RP-98-00737

Revision 0

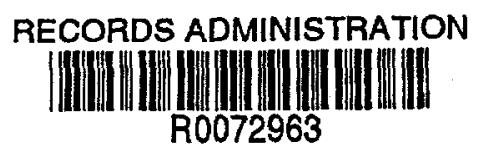

